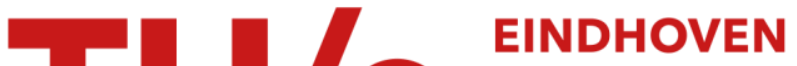 UNIVERSITY OF TECHNOLOGY
}

\section{Analysis of the predicted effect of passive climate adaptation measures on energy demand for cooling and heating in a residential building}

\author{
Citation for published version (APA): \\ van Hooff, T., Blocken, B., Timmermans, H. J. P., \& Hensen, J. L. M. (2016). Analysis of the predicted effect of \\ passive climate adaptation measures on energy demand for cooling and heating in a residential building. \\ Energy, 94, 811-820. https://doi.org/10.1016/j.energy.2015.11.036
}

\section{Document license: \\ TAVERNE}

DOI:

10.1016/j.energy.2015.11.036

Document status and date:

Published: 01/01/2016

\section{Document Version:}

Publisher's PDF, also known as Version of Record (includes final page, issue and volume numbers)

\section{Please check the document version of this publication:}

- A submitted manuscript is the version of the article upon submission and before peer-review. There can be important differences between the submitted version and the official published version of record. People interested in the research are advised to contact the author for the final version of the publication, or visit the $\mathrm{DOI}$ to the publisher's website.

- The final author version and the galley proof are versions of the publication after peer review.

- The final published version features the final layout of the paper including the volume, issue and page numbers.

Link to publication

\footnotetext{
General rights

- You may freely distribute the URL identifying the publication in the public portal. follow below link for the End User Agreement:

www.tue.nl/taverne

\section{Take down policy}

If you believe that this document breaches copyright please contact us at:

openaccess@tue.nl

providing details and we will investigate your claim.
}

Copyright and moral rights for the publications made accessible in the public portal are retained by the authors and/or other copyright owners and it is a condition of accessing publications that users recognise and abide by the legal requirements associated with these rights.

- Users may download and print one copy of any publication from the public portal for the purpose of private study or research.

- You may not further distribute the material or use it for any profit-making activity or commercial gain

If the publication is distributed under the terms of Article $25 \mathrm{fa}$ of the Dutch Copyright Act, indicated by the "Taverne" license above, please 


\title{
Analysis of the predicted effect of passive climate adaptation measures on energy demand for cooling and heating in a residential building
}

\author{
T. van Hooff ${ }^{\text {a, b, * }}$, B. Blocken ${ }^{\text {a, b }}$, H.J.P. Timmermans ${ }^{\text {c }}$, J.L.M. Hensen ${ }^{\text {a }}$ \\ a Building Physics and Services, Eindhoven University of Technology, Eindhoven, The Netherlands \\ ${ }^{\mathrm{b}}$ Building Physics Section, Leuven University, Leuven, Belgium

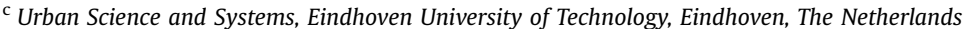

\section{A R T I C L E I N F O}

Article history:

Received 11 September 2015

Received in revised form 6 November 2015

Accepted 17 November 2015

Available online 20 December 2015

\section{Keywords:}

Building energy simulation

Climate change adaptation measures

Dwellings

Heating and cooling energy

Building performance

Future climate

\begin{abstract}
A B S T R A C T
Both new and existing buildings need to be adapted to climate change, in order to keep providing a comfortable and healthy indoor climate. Preferably, the adaptation measures applied at the building level scale do not require additional energy (i.e. passive measures). Previous studies showed that passive climate change adaptation measures can have a positive effect on thermal comfort in summer and its shoulder seasons in non-air-conditioned residential buildings. In this paper, the effect of these passive climate adaptation measures - applied at building component level - on the cooling and heating energy demand of a terraced house is analyzed using building energy simulations. It is shown that for this particular case the required cooling energy can be limited to a large extent (59-74\%) when external solar shading or additional natural ventilation is applied. In addition, it is shown that for a well-insulated terraced house the energy cost for heating is not strongly affected by the application of passive climate change adaptation measures.
\end{abstract}

(C) 2015 Elsevier Ltd. All rights reserved.

\section{Introduction}

The main conclusions in the reports by the IPCC (Intergovernmental Panel on Climate Change) that have been published in the last decade are clear: climate change is unmistakably occurring. In the latest report by the IPCC it is stated, for example, that the global average land and ocean surface temperature has increased with $0.85{ }^{\circ} \mathrm{C}\left(0.65-1.06{ }^{\circ} \mathrm{C}\right)$ from 1880 to 2012 [1]. In addition, it is reported that it is 'likely' that the frequency of heat waves has increased in large parts of Europe, Asia and Australia. Furthermore, in the Northern Hemisphere the 30-year period from 1983 to 2012 was 'likely' the warmest period in the last 1400 years [1].

In the Netherlands, climate change will most likely lead to a continuous rise of temperatures, resulting in milder winters and hotter summers with more heat waves during the summer [2]. While the occurrence of mild winters will decrease the energy demand for heating, the increasing number of hot summers can lead to problems regarding thermal comfort and health of building occupants, and to an increase of energy use in buildings with active cooling systems (e.g. Refs. [3-7]). If active cooling is applied in

\footnotetext{
* Corresponding author. Building Physics Section, Leuven University, Leuven, Belgium.

E-mail address: twan.vanhooff@bwk.kuleuven.be (T. van Hooff).
}

order to prevent people against excessive exposure to high indoor air temperatures, it is important to minimize the energy use for this purpose as much as possible. Otherwise, the use of active cooling systems will result in an increase in the use of fossil fuels, the emission of $\mathrm{CO}_{2}$, and a further acceleration of climate change in the future. In a recent report on the impact of climate change on buildings it is stated that the global energy demand for airconditioning in buildings is expected to increase from nearly $300 \mathrm{TWh}$ in 2000 to $4000 \mathrm{TWh}$ in 2050, if no additional mitigation policies are undertaken $[8,9]$. Maintaining a healthy and comfortable indoor environment without using excessive amounts of energy should be the goal when designing a new building, now and in the future. However, a too strong focus on only one of the aforementioned aspects might lead to a deterioration of the other aspect (e.g. Ref. [3]).

Although the majority of the residential buildings in the Netherlands and in many other North-Western European countries are typically neither equipped with an air-conditioning system, nor with other active cooling systems to reduce the indoor air temperature in hot periods $[10,11]$, the presence of small airconditioning systems to cool one or more rooms of a house appears to be growing [12-14]. In a EU report by Capros et al. [12] it is stated that the use of active cooling in residential buildings is limited in Europe, but will grow "at a fast pace" and will attain a 
share of almost $2 \%$ of the total energy use in residential buildings in Europe in 2030. Wu and Pett [13] reported that $10 \%$ of the nondomestic building floor area and $0.5 \%$ of the domestic building floor area in the UK was cooled in 2006 . However, they also stated that the growth in the domestic sector will be the fastest, and that the carbon emissions from these additional cooling efforts will overweigh the reduction in carbon emissions due to a decrease in heating demand in the UK in the future due to the changing climate [13]. Finally, they mentioned that air-conditioning units are often purchased in periods of distress (e.g. during heat waves) and that afterwards the air-conditioning will be used whenever the temperature will rise, even when the temperatures are lower than the ones that caused the distress and initiated the purchase, which will lead to an excessive use of the cooling systems [13]. Aebischer et al. [14] indicated the growth of the energy demand for cooling in Europe, due to - among others - climate change, higher internal loads, application of large glass facades (i.e. higher solar heat gains), higher thermal insulation values, and an increase in thermal comfort standards and expectations (e.g. resulting from airconditioned cars, trains and public spaces). As indicated also by $\mathrm{Wu}$ and Pett [13], in large parts of Europe (moderate climates) the cooling energy demand will be outweighed by a reduction in the heating demand [14]. However, the yearly total amount of $\mathrm{CO}_{2}$ emission can increase, depending on the percentages of cooling and heating in a specific country, and on the $\mathrm{CO}_{2}$ intensity of the heating fuels and electricity that are supplied to the buildings [14]. As indicated in the aforementioned publications, the application of (ad-hoc) energy-consuming measures to avoid indoor overheating should be stopped or at least limited, to avoid an increase of energy use and $\mathrm{CO}_{2}$ emission in the built environment in the near future. Previous studies have shown that passive climate change adaptation measures can significantly reduce the number of overheating hours in - among others - residential buildings that are not equipped with air-conditioning or active cooling systems (e.g. Refs. [15-21]). Note that none of these studies mentioned here assessed the influence of passive climate change adaptation measures on the energy demand for cooling, when an active cooling system would be present.

In this study, the cooling and heating demand of a residential building are analyzed, after which the effect of a range of passive climate change adaptation measures is assessed with respect to both the energy demand for cooling and heating, and for the total energy demand. This study is performed for a typical Dutch terraced house. The simulations are conducted for an expected future climate year, and a selected number of simulations has been conducted for an "average" climate year. A passive measure is defined in this study as a measure which does not use energy once it has been implemented. The following passive climate change adaptation measures are analyzed in this paper: (i) increased thermal resistance; (ii) changed thermal capacity; (iii) increased short-wave reflectivity (albedo value); (iv) vegetation roofs; (v) solar shading; and (vi) additional natural ventilation (see Table 1). In addition, the combined effect of several passive climate change adaptation measures is assessed. Dynamic thermal simulations using EnergyPlus [22] are performed to analyze the effect of the different measures on the yearly energy demand for heating and cooling.

The research was conducted within the Climate Proof Cities (CPC) research consortium, which was one of the research consortia investigating the climate vulnerability of urban areas and the development and effectiveness of climate change adaptation measures [21,23-35]. The methodology will be addressed in Section 2, after which the results of the dynamic thermal simulations will be presented in Section 3. Section 4 (discussion), Section 5 (conclusions), and Section 6 (future work) conclude this paper.

\section{Methodology}

Dynamic thermal simulations are performed with EnergyPlus to assess the performance of the different passive adaptation measures. EnergyPlus consists of three basic components: (1) a simulation manager, (2) a heat and mass balance simulation module, (3) a building systems simulation module [36]. The development of EnergyPlus is funded by the DOE (Department of Energy) of the US and has been validated extensively in the past (e.g. Refs. [37-40]). In addition, the authors have performed several successful comparisons of EnergyPlus results with data from the BESTEST (Building Energy Simulation Test). More background information on EnergyPlus and validation tests can be found in Refs. [22,36-42].

\subsection{Building description}

The building geometry of the terraced house is based on an example terraced house in the Netherlands as defined by Agentschap NL [43]. It has one zone for the living room (ground floor),

Table 1

Overview of adaptation measures studied.

\begin{tabular}{|c|c|c|}
\hline Adaptation measure & Description & Abbreviation \\
\hline Increased thermal resistance & $\begin{array}{l}\text { The thermal resistance of all external building surfaces is increased to } R_{C}=5.0 \mathrm{~m}^{2} \mathrm{~K} / \mathrm{W}\left(\mathrm{U}=0.2 \mathrm{~W} / \mathrm{m}^{2} \mathrm{~K}\right) \text { and } \\
\mathrm{R}_{\mathrm{C}}=6.5 \mathrm{~m}^{2} \mathrm{~K} / \mathrm{W}\left(\mathrm{U}=0.15 \mathrm{~W} / \mathrm{m}^{2} \mathrm{~K}\right) \text {, for RC50 and RC65, respectively. This measure is implemented by increasing } \\
\text { the thickness of the insulation layers. }\end{array}$ & RC50, RC65 \\
\hline Changed thermal capacity & $\begin{array}{l}\text { The thermal capacity is lowered, since the base case is a heavy building. The thermal capacity is changed by } \\
\text { replacing the limestone inner leaf by an inner leaf of wooden sheeting. In addition, concrete ceilings are replaced } \\
\text { by wooden constructions. }\end{array}$ & TM_low \\
\hline $\begin{array}{l}\text { Increased short-wave reflectivity } \\
\text { (albedo) }\end{array}$ & The short-wave reflectivity value of the external surfaces is increased from the default value of $0.3-0.8$. & SWR08 \\
\hline Vegetated roof & The default roof constructions are extended to incorporate a vegetated roof with a Leaf Area Index (LAI) of 5. & VR \\
\hline Solar shading & $\begin{array}{l}\text { Exterior solar shading is applied for all windows on the east, south and west side of the facades. The solar } \\
\text { shading is automatically lowered when the indoor air temperature is } 21^{\circ} \mathrm{C} \text { or higher and when at the same time } \\
\text { solar radiation on the window is at least } 150 \mathrm{~W} / \mathrm{m}^{2} \text {. }\end{array}$ & $\mathrm{SH}$ \\
\hline Additional natural ventilation & $\begin{array}{l}\text { Additional natural ventilation is provided by opening (parts of) the windows. The windows will be opened when } \\
\text { the indoor air temperature is above } 24^{\circ} \mathrm{C} \text {, but only when the indoor air temperature is higher than the outdoor } \\
\text { air temperature. The windows can be opened the entire day }(24 \mathrm{~h} \text { ). }\end{array}$ & NV \\
\hline
\end{tabular}


one zone for the bedrooms (first floor), and a third zone, which consists of the attic. It is assumed that four occupants are present in the terraced house; two adults and two children. The simulations are conducted for four different orientations of the facade in which the entrance is situated $\left(0^{\circ}, 90^{\circ}, 180^{\circ}, 270^{\circ}\right)$, enabling an assessment of the influence of window orientation in combination with solar radiation.

The ground plans and building facades are depicted in Fig. 1. The three floors of the building each have a surface area of $45.5 \mathrm{~m}^{2}$, and the total net indoor volume is about $348 \mathrm{~m}^{3}$. Two sides of the building are exposed to the ambient conditions; adiabatic conditions are assumed for the two other sides that share an internal wall with adjacent terraced houses.

Residential buildings in the Netherlands are very often heavyweight buildings, i.e. concrete and stone materials are used for the floors and both sides of the cavity walls. Therefore, the base case building is also a heavy-weight building. The insulation values of the base case building are in accordance with the building regulations in the Netherlands in 2012 [45]. In addition, simulations have been performed for a lower value of the thermal resistance of the building envelope, which corresponds to a building built in the 1970 s (i.e. named RC04). These simulations are performed to assess the cooling and heating energy demand for older buildings compared to new buildings. Table 2 provides an overview of the construction details of the base case building, whereas Table 3 provides this information for the building from the 1970s. Note that the range of passive climate change adaptation measures is only applied for the base case building.

The building is conditioned using an all-air system with a heating coil and a direct expansion cooling coil. Note that an all-air system, and, as mentioned before, air-conditioning or active cooling systems are not commonly applied in residential buildings in the Netherlands, and also not in several other North-Western European countries $[10,11]$. However, the aim of this study is to provide an insight in the amount of energy that would be used, and thus could be saved, when residents do apply air-conditioning systems in their houses, either in the Netherlands, or other countries in a similar climate. No shading devices are present in the base case situation, which is currently common for newly built residential buildings in the Netherlands. The all-air system that is present ensures a
Front facade
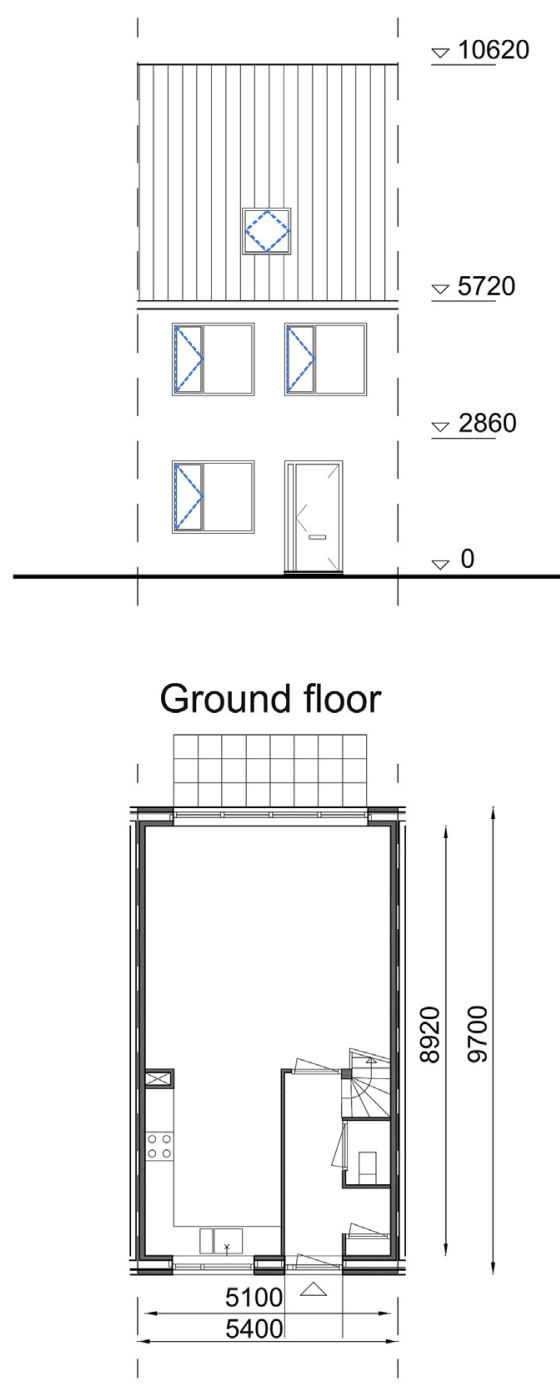

\section{Back facade}

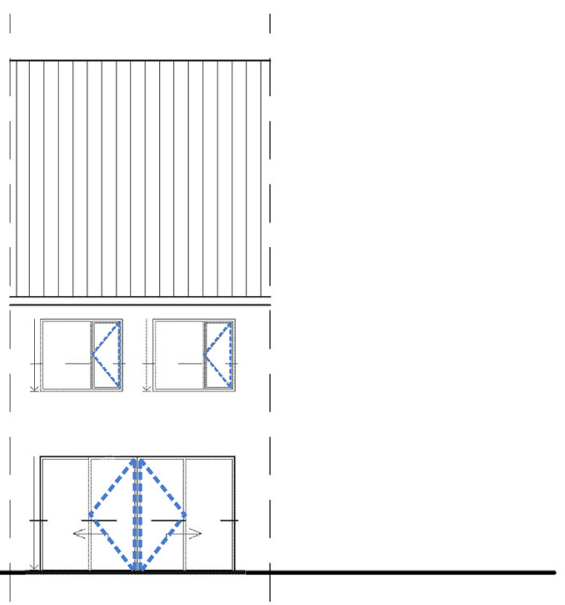

First floor

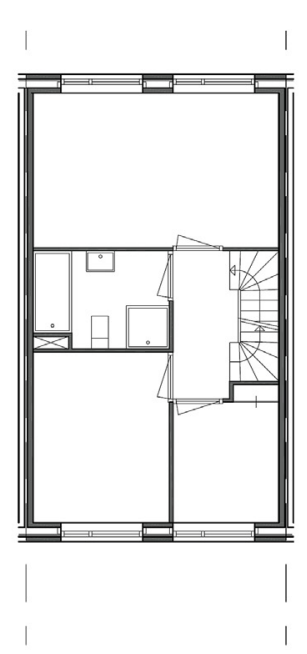

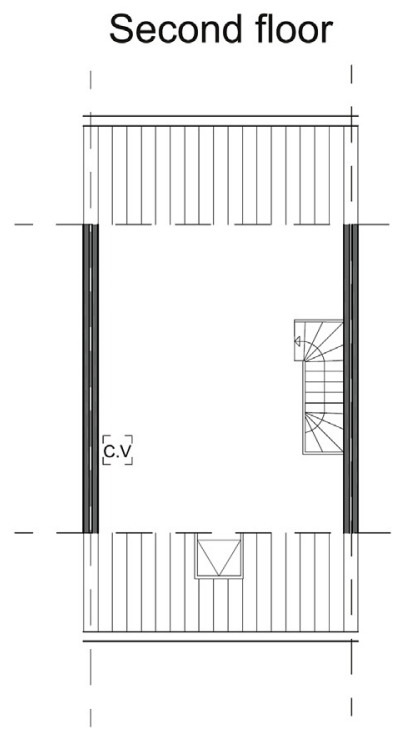

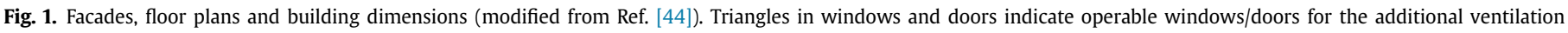
configuration. Dimensions in $\mathrm{mm}$. 
Table 2

Overview of construction details for the base case building from 2012.

\begin{tabular}{llll}
\hline Element & Details & $\mathrm{R}_{\mathrm{C}}\left(\mathrm{m}^{2} \mathrm{~K} / \mathrm{W}\right)$ & $\mathrm{U}\left(\mathrm{W} / \mathrm{m}^{2} \mathrm{~K}\right)$ \\
\hline External walls & $\begin{array}{l}\text { Cavity walls with (inside to } \\
\text { outside): }\end{array}$ & 3.5 & 0.29 \\
& $\begin{array}{l}\text { Limestone inner leaf, insulation, } \\
\text { air cavity, brick outer leaf }\end{array}$ & - & - \\
Internal wall & $\begin{array}{l}\text { Limestone wall } \\
\text { Inside to outside: Wooden } \\
\text { Roof (pitched) }\end{array}$ & 4 & 0.25 \\
& $\begin{array}{l}\text { sheeting, } \\
\text { insulation layer, air cavity, roof }\end{array}$ & & 0.29 \\
tiles. & $\begin{array}{l}\text { Inside to outside: Concrete, } \\
\text { insulation } \\
\text { Concrernal floor }\end{array}$ & 3.5 & - \\
Internal floor & $\begin{array}{l}\text { Double pane glazing. Solar } \\
\text { Windows }\end{array}$ & - & 1.65 \\
\hline
\end{tabular}

Table 3

Overview of construction details for the base case building from the 1970s.

\begin{tabular}{|c|c|c|c|}
\hline Element & Details & $\mathrm{R}_{\mathrm{C}}\left(\mathrm{m}^{2} \mathrm{~K} / \mathrm{W}\right)$ & $\mathrm{U}\left(\mathrm{W} / \mathrm{m}^{2} \mathrm{~K}\right)$ \\
\hline External walls & $\begin{array}{l}\text { Cavity walls with (inside to } \\
\text { outside): } \\
\text { Limestone inner leaf, air cavity, } \\
\text { brick outer leaf. }\end{array}$ & 0.4 & 2.5 \\
\hline Internal wall & Limestone wall & - & - \\
\hline Roof (pitched) & $\begin{array}{l}\text { Inside to outside: Wooden } \\
\text { sheeting, insulation layer, air } \\
\text { cavity, } \\
\text { roof tiles. }\end{array}$ & 0.8 & 1.25 \\
\hline External floor & Concrete & 0.17 & 5.88 \\
\hline Internal floor & Concrete & - & - \\
\hline Windows & $\begin{array}{l}\text { Single pane glazing. } \\
\text { Solar transmittance } \\
\text { coefficient }=0.7 \text {. }\end{array}$ & - & 5.2 \\
\hline
\end{tabular}

constant ventilation flow rate of $0.7 \mathrm{dm}^{3} / \mathrm{sm}^{2}$ [44]. The infiltration flow rate is set to $0.2 \mathrm{ACH}$ [45]. Note that the adaptation measure regarding natural ventilation (NV) assumes that windows will be opened to allow ventilative cooling when the indoor temperature is higher than the outdoor temperature, which therefore results in an additional airflow on top of the basic ventilation flow rates as mentioned above.

Table 4 Lists the air temperature heating setpoints (based on [46]), and the cooling setpoint is set to $24^{\circ} \mathrm{C}$ (based on e.g. Ref. [45]). Table 5 shows the indoor heat gains for the ground floor (living room) and first floor (bedrooms) (based on [45] and [47]).

\subsection{Adaptation measures}

The studied passive climate change adaptation measures are listed below. For more detailed information and a literature study on these measures the reader is referred to van Hooff et al. [21].

\subsubsection{Thermal resistance}

The prescribed thermal resistance ( $R_{C}$ value) for all closed parts of the building envelope should be at least $\mathrm{R}_{\mathrm{C}}=3.5 \mathrm{~m}^{2} \mathrm{~K} / \mathrm{W}$ in the Netherlands ( $\mathrm{U}=0.29 \mathrm{~W} / \mathrm{m}^{2} \mathrm{~K}$ ), according to the building code of 2012, and the $U$ value (thermal transmittance) for the doors and

Table 4

Temperature setpoints for heating (based on [46]).

\begin{tabular}{llll}
\hline & \multicolumn{3}{l}{ Time interval [hour] } \\
\cline { 2 - 4 } & $06: 00-18: 00$ & $18: 00-23: 00$ & $23: 00-06: 00$ \\
\hline Temperature setpoint & $19{ }^{\circ} \mathrm{C}$ & $20^{\circ} \mathrm{C}$ & $16{ }^{\circ} \mathrm{C}$ \\
\hline
\end{tabular}

Table 5

Heat gains inside the building (based on [45] and [47]).

\begin{tabular}{clllll}
\hline \multirow{2}{*}{ Zone } & Heat & \multicolumn{5}{l}{ Time interval [hour] } \\
\cline { 3 - 6 } & source & $06: 00$ & $18: 00$ & $19: 00$ & $23: 00$ \\
& & $-18: 00$ & $-19: 00$ & $-23: 00$ & $-06: 00$ \\
\hline Living & Appliances & $25 \mathrm{~W}$ & $100 \mathrm{~W}$ & $100 \mathrm{~W}$ & $25 \mathrm{~W}$ \\
room & Kitchen & $250 \mathrm{~W}$ & $600 \mathrm{~W}$ & $250 \mathrm{~W}$ & - \\
& Persons & - & $385 \mathrm{~W}$ & $385 \mathrm{~W}$ & - \\
& Lighting & - & - & $15 \mathrm{~W} / \mathrm{m} 2$ & - \\
\multirow{2}{*}{ Bedrooms } & Persons & - & - & - & $241 \mathrm{~W}$ \\
\hline
\end{tabular}

windows should be $\mathrm{U}=1.65 \mathrm{~W} / \mathrm{m}^{2} \mathrm{~K}$ or lower [44]. As indicated in van Hooff et al. [21] and Aebischer et al. [14], an unwanted effect of increasing insulation levels of opaque and transparent parts of the building envelope during summer (warm days) is the fact that once a high indoor temperature is reached, for example due to solar radiation through the transparent parts (glass) of the building envelope or due to internal heat gains, it will also be maintained for a longer period than in the case of lower thermal resistances. In this study, the effect of two alternative values of the thermal resistance of the closed parts of the building envelope are analyzed: $\mathrm{R}_{\mathrm{C}}=5.0 \mathrm{~m}^{2} \mathrm{~K} / \mathrm{W}(\mathrm{RC} 50)\left(\mathrm{U}=0.2 \mathrm{~W} / \mathrm{m}^{2} \mathrm{~K}\right)$ and $\mathrm{R}_{\mathrm{C}}=6.5 \mathrm{~m}^{2} \mathrm{~K} / \mathrm{W}$ (RC65) $\left(\mathrm{U}=0.15 \mathrm{~W} / \mathrm{m}^{2} \mathrm{~K}\right)$. Note that the energy demand for a building with low values of the thermal resistance is also calculated (RC04).

\subsubsection{Thermal mass}

The amount of available thermal mass varies for each building and depends on the material that has been used for the different building components. A distinction can be made between heavyweight buildings $\left(>85 \mathrm{~kg} / \mathrm{m}^{2}\right)$, and light-weight buildings $\left(<20 \mathrm{~kg} / \mathrm{m}^{2}\right)$, referring to the amount of thermal mass that is available for thermal storage per visible surface area (either a wall, a floor or ceiling, adjacent to indoor air) (e.g. Ref. [45]). As mentioned in Section 2.1 most residential buildings in the Netherlands are heavy-weight buildings due to the use of concrete, brick, and other heavy building materials. Therefore, the base case building is a heavy-weight building. In the alternative case (TM_low) the amount of thermal mass is reduced by assuming that the inner leaf of the building envelope consists of wooden sheets instead of limestone, and the ceilings consist of a wooden construction instead of concrete. Therefore, this is the inverse of adaptation. Nevertheless, it serves to illustrate the effects of thermal storage on energy use.

\subsubsection{Short-wave reflectivity}

The short-wave reflectivity (albedo value) of a surface determines the fraction of incoming short-wave radiation that is being reflected. In the built environment, common values for the short-wave reflectivity are about 0.3 for red brick materials and roof tiling [48]. This value for the short-wave reflectivity is taken for the facades and the roof in the base case, and as an alternative case this value is increased to 0.8 (SWR08), which corresponds to shortwave reflectivity values from literature [48].

\subsubsection{Vegetated roofs}

Extensive vegetated roofs are added to the building (VR), since this type of vegetated roof has less implications for the roof construction and can therefore be more easily applied on new and on existing buildings. Extensive vegetated roofs can be distinguished from intensive vegetated roofs; it can be assumed that extensive roofs generally have vegetation lower than $0.15 \mathrm{~m}$ and intensive roofs have vegetation higher than $0.15 \mathrm{~m}$ [49] (and are therefore heavier and more demanding for the roof construction). The height 
of the vegetation is taken equal to $0.1 \mathrm{~m}$, which represents the height of sedum plants, which are often used as extensive roof vegetation. The Leaf Area Index (LAI) is set to 5. Scurlock et al. [50] defined the LAI as the functional vegetated leaf area of the canopy $\left(\mathrm{m}^{2}\right)$ per area of ground $\left(\mathrm{m}^{2}\right)$. A LAI value of 5 is relatively high, but it is chosen to assess the upper bounds of the effects of an "ideal" extensive vegetated roof.

\subsubsection{Solar shading}

Solar shading is not yet commonly applied in residential buildings in the Netherlands and surrounding countries. In this study it is assumed that all the windows on the east, south and west facade of the building are equipped with automatic vertical exterior solar shading devices with a solar reflectivity of 0.9 . The threshold for lowering the solar shading is set to a zone air temperature of $21{ }^{\circ} \mathrm{C}$ and a simultaneous occurrence of solar radiation on the window (beam and diffuse) of $150 \mathrm{~W} / \mathrm{m}^{2}$ or more (e.g. Ref. [51]). By setting a double threshold, i.e. a minimum indoor air temperature in addition to the solar radiation limit, solar irradiation can be optimally utilized to reduce the building heating demand in the heating season.

\subsubsection{Natural ventilation}

Addition natural ventilation by opening windows can be seen as a passive adaptation measure. Therefore, it is assumed that the windows in the base case are closed throughout the day. In this study it is assumed that the windows will be opened above a threshold indoor air temperature of $23^{\circ} \mathrm{C}$. An additional requirement is that the indoor air temperature should be higher than the outdoor air temperature in order to prevent an undesired increase of the indoor air temperature. The opening area of the windows is indicated by the triangular shapes in the windows in Fig. 1. The windows will be systematically and automatically opened when the given thermal criterion is met, irrespective of the time of the day.

\subsection{Weather data}

The weather data that has been used are those measured in De Bilt, the Netherlands, during 2006, which was a much warmer year than normal with several heat waves during the summer, and can therefore be seen as a representation of a climate year with a summer period that will be more common in the future $[52,53]$. The winter in 2006 was slightly warmer than the average winter in the past 20 years; the total number of heating degree days [47], determined with a base temperature of $18{ }^{\circ} \mathrm{C}$, for the average and future climate amounts 2895 and 2751, respectively [52,54]. In Section 3.1 a comparison is made between the predicted energy demands for heating and cooling using weather data for an average climate year and for a future climate year. Please note that the aim of this study is not to provide absolute values of the heating and cooling demand for a future climate, but to provide insights in the energy demand for cooling, and in possible synergy effects and conflicts when passive adaptation measures are applied with respect to the heating, cooling and total yearly energy demand.

\subsection{Additional simulation parameters}

The dynamic thermal simulations are conducted using six time steps per hour, as recommended by EnergyPlus [41]. The number of time steps per hour is increased to 60 for the simulations with the vegetated roof, as recommended by EnergyPlus [41], to improve the numerical solution of the zone heat balance model and to obtain more accurate results. The ground temperature at a depth of $1 \mathrm{~m}$ is taken equal to $10^{\circ} \mathrm{C}$, and the ground reflection is set to 0.2 . The surface convection algorithms used for the interior and exterior building surfaces are TARP and DOE-2, respectively (e.g. Ref. [55]). To incorporate the (natural) ventilation flow the airflow network included in EnergyPlus is used. The wind pressure coefficients to calculate the volume flow rate have been obtained from Liddament [56]; wind pressure coefficients for a building surrounded by obstructions equal to the height of the building under study are used.

\subsection{Performance indicators}

The performance of the climate change adaptation measures is assessed based on (1) yearly energy demand for cooling $\left(\mathrm{kWh} / \mathrm{m}^{2}\right)$; (2) yearly energy demand for heating $\left(\mathrm{kWh} / \mathrm{m}^{2}\right)$; (3) yearly total energy demand $\left(\mathrm{kWh} / \mathrm{m}^{2}\right)$. The yearly energy demand for cooling and heating is based on the temperature setpoints as mentioned in Section 2.1.

\section{Results}

\subsection{Average climate vs. future climate}

For the base case building and for RC04, RC50 and RC65, a comparison is made of the predicted energy demand determined for the currently used climate year in building energy performance simulations for determining heating and cooling demands in the Netherlands, and for the climate as measured in 2006 [52], which can be considered as a future climate year (certainly with respect to the summer season, and to some extent also for the heating season). The currently used climate year is obtained from NEN 5060 [54] which is based on EN ISO 15927-4 [57]. This climate year is calculated based on the climate of the past 20 years (1986-2005).

Fig. 2 shows the results of this comparison. Fig. 2a clearly shows a strong increase in the yearly energy demand for cooling averaged over the four orientations when the same building is subjected to the future climate; the increase is around $400 \%$ for the poorly insulated building (RC04) and slightly less than $200 \%$ for the other three cases. The amount of energy for cooling is the lowest for case RC04, which can be attributed to the fact that heat can more easily be transferred through the building envelope once it is inside the building due to, for example solar radiation through the transparent parts of the building envelope. This counter-intuitive effect was indicated earlier in a previous study by the authors [21] as well as by Aebischer et al. [14]. Fig. 2b shows the yearly energy demand for heating averaged over the four orientations for both the average climate and the future climate. It can be seen that there is a decrease in yearly energy demand, which can be attributed to the warmer winter in the future climate file used for this study (less heating degree days). The decrease is around $8 \%$ for all four cases. The total yearly energy demand averaged over the four orientations is depicted in Fig. 2c, which shows that the total yearly energy demand tends to decrease, which is the result of a larger decrease in heating demand than the increase in cooling demand.

\subsection{Passive adaptation measures}

Fig. 3 shows the yearly energy demand for cooling in $\mathrm{kWh} / \mathrm{m}^{2}$ for both the base case and for the cases with the different passive climate adaptation measures included. The columns indicate the average value over the four different orientations while the error bars indicate the minimum and maximum value. As indicated in Section 3.1, the terraced house from the 1970s (RC04) with low insulation values has a lower energy demand for cooling than the terraced houses with higher insulation values, i.e. the base case and RC50 and RC65. Applying less thermal mass results in an increase of energy demand of $16 \%$ compared to the base case building. This 
a

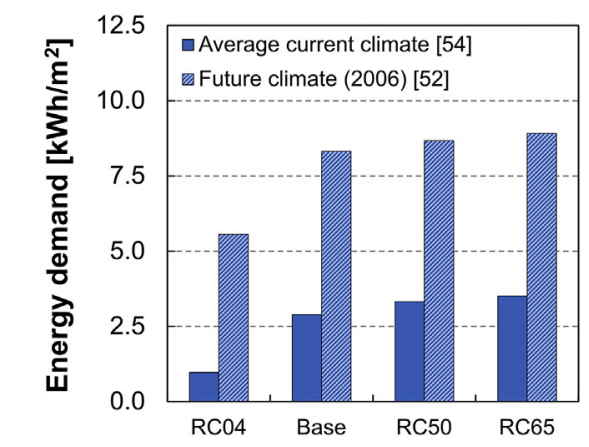

C

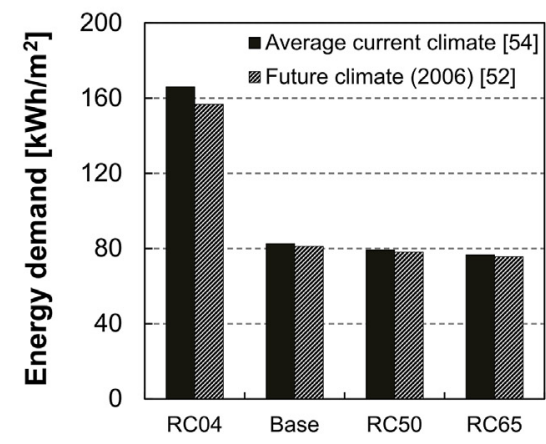

b

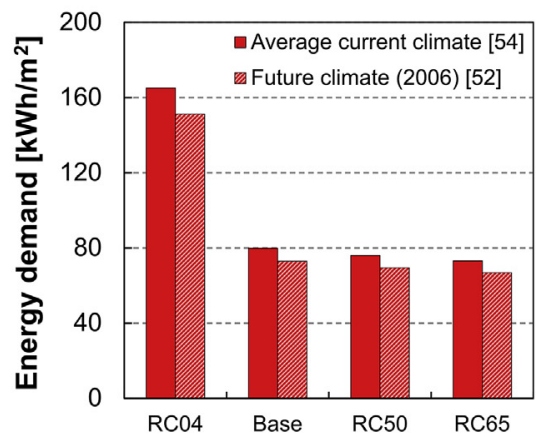

Fig. 2. Comparison of yearly energy demand in the current climate [54] and a future climate [52] in kWh/m². Energy demand for: (a) Cooling. (b) Heating. (c) Total.

increase in cooling energy demand is the result of the lower amount of thermal storage that is available in both the inner leaf of the external walls and in the inner walls (wooden sheets instead of limestone), as well as in the ceilings (wooden construction instead of concrete). When less thermal mass is present in the constructions which are exposed to the indoor conditions, less thermal storage is available for heat gains from solar radiation and internal heat sources, which will either lead to a higher indoor air temperature if no active cooling would be present (e.g. Refs. [21,58-61]), or a higher cooling demand if active cooling is available, as in the current study and as reported in previous studies (e.g. Refs. [62-64]). Thermal mass in buildings both delays and reduces peak indoor air temperatures and can thus have a positive effect on the cooling energy demand. Increasing the albedo value of

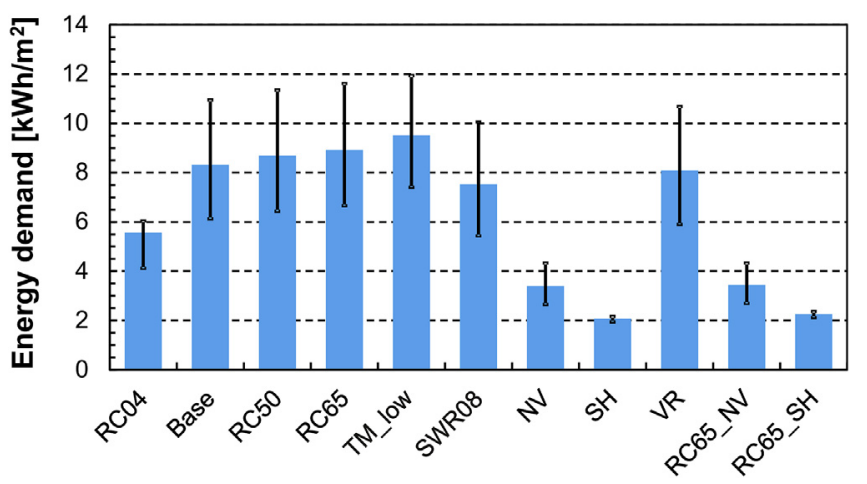

Fig. 3. Yearly energy demand $\left(\mathrm{kWh} / \mathrm{m}^{2}\right)$ for cooling for the base case building and for the different alternative building configurations. The columns represent the average energy demand over four different orientations, the error bars provide information on the minimum and maximum values. the building envelope to 0.8 (SWR08) decreases the mean energy demand for cooling by $10 \%$, while a vegetated roof (VR) only results in a decrease of $3 \%$. Applying solar shading ( $\mathrm{SH}$ ) and additional natural ventilation (NV) have the largest impact on energy demand for cooling with a decrease of $74 \%$ and $59 \%$, respectively. Applying additional natural ventilation and solar shading to a highlyinsulated building (RC65_NV and RC65_SH) can reduce the cooling energy demand considerably as well. Finally, it is shown that large differences are present for the different orientations, as a result of the different solar heat gain levels for the four different orientations.

Fig. 4 shows the yearly energy demand for heating in $\mathrm{kWh} / \mathrm{m}^{2}$. Obviously, the poorly-insulated building from the 1970s (RC04) requires by far the highest amount of energy for heating; i.e. 107\% more than the base case building. The energy demand for heating of a terraced house from the 1970 s (RC04) can be reduced with $57 \%$ if one would increase the thermal resistance to $R_{C}=6.5 \mathrm{~m}^{2} \mathrm{k} / \mathrm{W}$ $\left(\mathrm{U}=0.15 \mathrm{~W} / \mathrm{m}^{2} \mathrm{~K}\right)$. Increasing the insulation values for the base case building (building from 2012) only results in a relatively small decrease of the yearly energy demand of $5 \%$ and $8 \%$, for case RC50 and RC65, respectively. A reduction of the amount of thermal mass and an increase of the albedo value result in a very small increase of the energy demand ( $1-2 \%)$, which can be regarded as negligible. The application of an extensive vegetated roof results in a very small decrease of the yearly energy demand for heating $(-2 \%)$, which can be attributed to the slightly increased value of the thermal resistance of the roof due to the addition of the vegetated roof (soil, etc.). Applying automated external solar shading based on the indoor air temperature $\left(21^{\circ} \mathrm{C}\right)$ and on the total solar irradiation on the window $\left(\mathrm{E}>150 \mathrm{~W} / \mathrm{m}^{2}\right)$ does not affect the energy demand for heating much. However, note that automated solar shading that is only controlled by solar radiation on the window will prevent solar radiation from entering the building in the 


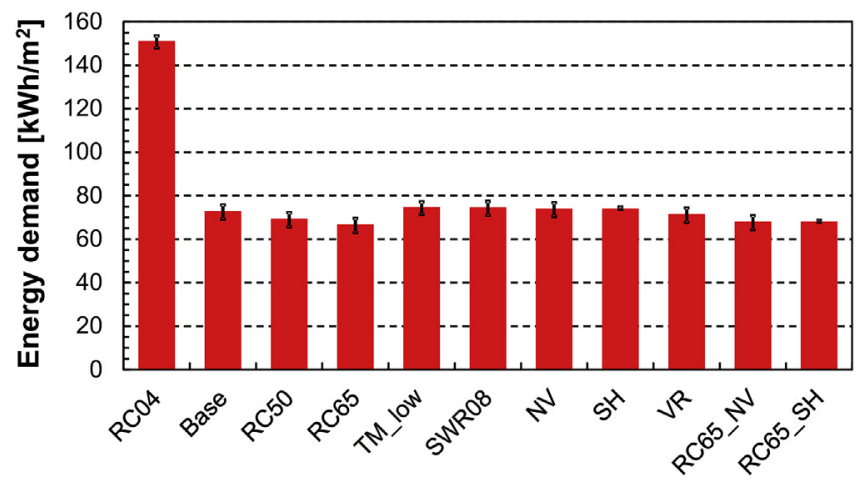

Fig. 4. Yearly energy demand $\left(\mathrm{kWh} / \mathrm{m}^{2}\right)$ for heating for the base case building and for the different alternative building configurations. The columns represent the average energy demand over four different orientations, the error bars provide information on the minimum and maximum values.

heating season, and will result in a higher energy demand for heating.

Fig. 5 shows the total yearly energy demand for heating and cooling, as percentage of the total yearly energy demand for the base case building. The building with low thermal insulation values (RC04) requires 93\% more energy for heating and cooling than the base case building, which is due to a substantially higher energy demand for heating (energy demand for cooling is less than for base case building; see Fig. 3). The terraced houses with higher insulation values, RC50 and RC65, have a 4\% and 7\% lower yearly energy demand compared to the base case house, respectively. The energy demand of a terraced house with a lower thermal mass is $4 \%$ higher, and for the terraced house with a higher albedo value it is almost equal, i.e. the advantage in the cooling season is cancelled out by a negative effect in the heating season. The application of a vegetated roof results in a $2 \%$ lower total yearly energy demand. Providing additional natural ventilation results in a decrease of energy demand with $5 \%$, and the use of solar shading comes with a decrease of $6 \%$ in the total yearly energy demand. Finally, the lowest total amount of energy is used in the terraced house with high insulation values $\left(R_{C}=6.5 \mathrm{~m}^{2} \mathrm{~K} / \mathrm{W}\right.$; $\left.\mathrm{U}=0.15 \mathrm{~W} / \mathrm{m}^{2} \mathrm{~K}\right)$ in combination with either the application of additional natural ventilation $(-12 \%)$ or of external solar shading, i.e. $-13 \%$ compared to the base case. The decrease in energy demand due to an increase of the thermal resistance from $R_{C}=3.5 \mathrm{~m}^{2} \mathrm{~K} / \mathrm{W}\left(\mathrm{U}=0.29 \mathrm{~W} / \mathrm{m}^{2} \mathrm{~K}\right)$ to $\mathrm{R}_{\mathrm{C}}=6.5 \mathrm{~m}^{2} \mathrm{~K} / \mathrm{W}\left(\mathrm{U}=0.15 \mathrm{~W} / \mathrm{m}^{2} \mathrm{~K}\right)$ is about equal to the decrease in total yearly energy demand when applying external solar shading or additional natural ventilation.

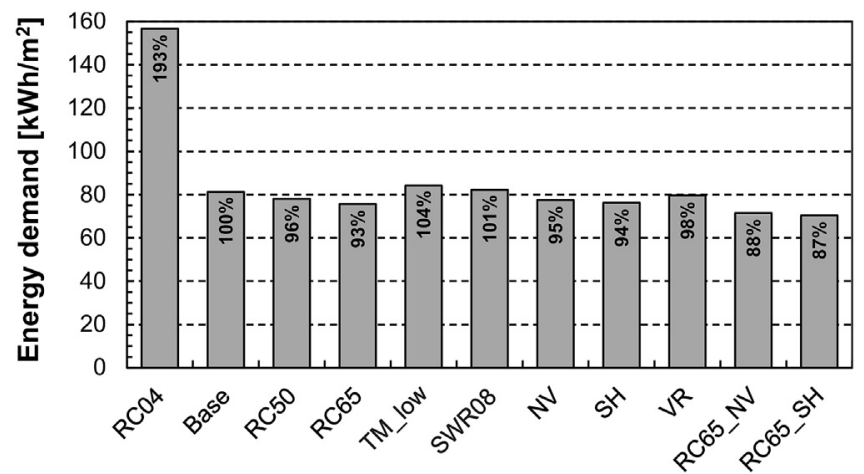

Fig. 5. Yearly energy demand for heating and cooling $\left(\mathrm{kWh} / \mathrm{m}^{2}\right)$ compared to the base case building (=100\%).

\section{Discussion}

This paper presented dynamic thermal simulations using EnergyPlus to assess the heating and cooling demand for a terraced house for both a base case building, and for the same building with a range of different passive climate change adaptation measures applied. In Section 4.1 a discussion is presented concerning the application of passive adaptation measures and possible unexpected effects on the total energy demand, depending on the construction year and insulation value of the building under renovation. Subsequently, a discussion on the balance between heating and cooling demands is presented in Section 4.2. Note that the limitations of the current study and directions for future research are listed in Section 6.

\subsection{Possible adverse effect of passive adaptation measures on energy demand}

Application of passive climate change adaptation measures with the aim to reduce the amount of indoor overheating or the cooling demand should be done only after careful consideration and analysis of the building under renovation, since the effects can differ per building type, construction year, insulation level, etc. For example, increasing the value of the short-wave reflectivity is known to have a positive effect on indoor air temperatures and cooling demand in summer (Fig. 3 and, e.g. Refs. [21,65-68]). However, it can also have negative consequences during the heating season since higher short-wave reflectivity values reflect more solar radiation and lead to lower surface temperatures. In van Hooff et al. [21] it was shown that the effect of - among others - changing the short-wave reflectivity value on indoor air temperatures was more pronounced for poorly insulated buildings. The question arises what the net effect will be of a reduction of short-wave reflectivity of a residential building with a low overall thermal insulation value on the total energy demand. To answer this question, additional simulations were performed to assess the influence of the short-wave reflectivity on energy demand in both the heating and the cooling season for the poorly insulated terraced building (RC04). Fig. 6 shows the yearly energy demand for cooling, heating and in total in $\mathrm{kWh} / \mathrm{m}^{2}$ for a poorly insulated building with normal values of the short-wave reflectivity, and with high values of the short-wave reflectivity $(0.8)$ for both the average climate year and the future climate year. It can be seen that the cooling demand is reduced to zero when applying high values of the short-wave reflectivity. However, the energy demand for heating is increased with slightly more than $11 \%$. The total yearly energy demand when higher values of the short-wave reflectivity are applied increases with almost $11 \%$ for the current climate and with $8 \%$ for the future climate. These results show that careful consideration is needed in the implementation of passive climate change adaptation measures in the design and retrofitting of residential buildings, since certain measures that work well as climate change adaptation measures can have a negative impact on the yearly energy demand, and vice versa. In addition, the total predicted effect of some of the climate change adaptation measures on the total yearly energy demand can depend - among others - on the properties of the building envelope, as illustrated in this section.

\subsection{Ratio cooling vs. heating demand}

Comparison of Figs. 3 and 4 shows that for the Dutch climate, which is a maritime temperate climate according to the Köppen climate classification [69], the energy demand in the heating season is considerably larger, (around $90 \%$ of the yearly total) than the 


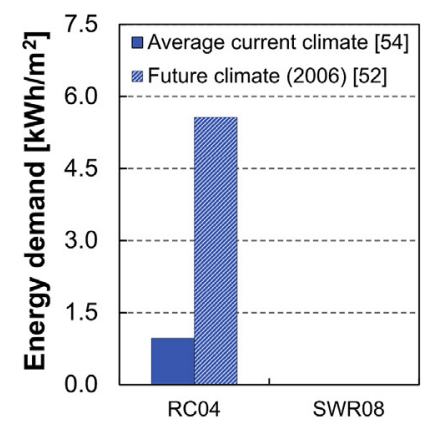

b

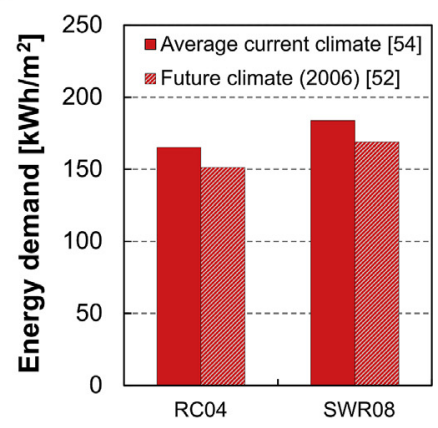

C

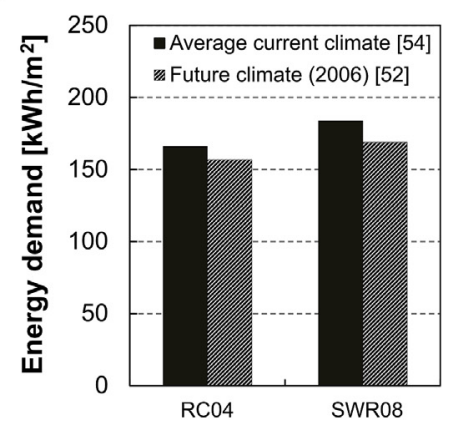

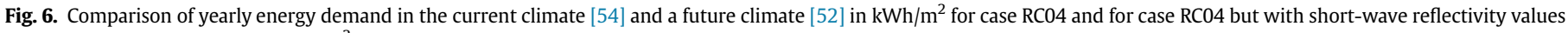
of 0.8 . Yearly energy demand $\left(\mathrm{kWh} / \mathrm{m}^{2}\right)$ for: (a) Cooling. (b) Heating. (c) Total.

energy demand for cooling, which is around $10 \%$ of the total yearly energy demand for cooling and heating. However, the percentage of the total energy demand that is associated with cooling will increase in the future due to climate change (milder winters and hotter summers), the urban heat island effect, better insulated and more airtight buildings, etc. (e.g. Ref. [14]). Although 10\% for cooling appears to be small compared to the $90 \%$ for heating, it must be noted that it is shown that passive climate change adaptation measures, such as external solar shading and additional natural ventilation, can almost prevent the use of active cooling in residential buildings and can save roughly $7-8 \mathrm{kWh} / \mathrm{m}^{2}$ per year (i.e. around $10 \%$ reduction of yearly total energy demand), which is still a considerable possible decrease. In fact, these measures result in a decrease of the total yearly energy demand which is almost equally large as the decrease that would be obtained when increasing the thermal resistance of the building envelope from $R_{C}=3.5 \mathrm{~m}^{2} \mathrm{~K} / \mathrm{W}$ $\left(\mathrm{U}=0.29 \mathrm{~W} / \mathrm{m}^{2} \mathrm{~K}\right)$ to $\mathrm{R}_{\mathrm{C}}=6.5 \mathrm{~m}^{2} \mathrm{~K} / \mathrm{W}\left(\mathrm{U}=0.15 \mathrm{~W} / \mathrm{m}^{2} \mathrm{~K}\right)$. Furthermore, note that the weather data used in this study provides an indication of future hot summers, but the air temperatures in winter for the future climate year are only slightly higher. Therefore, it is expected that the contribution of the yearly heating demand to the yearly total energy will most probably be lower in the future than calculated in this study.

\section{Conclusions}

This study presents the results of a computational analysis of the heating and cooling demand of a terraced house and the influence of six different passive climate change adaptation measures at the building component scale on these energy demands. The analysis has been performed using dynamic thermal simulations with EnergyPlus. From this study the following conclusions can be made:

- The energy demand for cooling is the highest for the wellinsulated houses without solar shading or additional natural ventilation. Lower insulation levels lead to lower energy demands for cooling. Application of solar shading and/or additional natural ventilation can reduce the energy demand for cooling considerably; with $74 \%$ and $59 \%$ respectively. When less thermal mass is applied this has a negative effect on the energy demand for cooling, which increases with $16 \%$.

- The energy demand for heating is mainly dependent on the insulation values. Application of passive climate change adaptation measures hardly influences the energy demand for heating; i.e. within $2 \%$ of the heating demand of the base case building. The energy demand for the terraced house from the 1970s with low insulation values (RC04) is two times higher than for the other cases.

- The influence of a high albedo values or a vegetated roof on the total energy demand for heating and cooling is negligible; it remains within $2 \%$. A lower thermal mass leads to an increase of the total energy demand of $4 \%$. The total energy demand is the lowest for the well-insulated houses in combination with either solar shading (RC65_SH) or additional natural ventilation (RC65_NV); requiring $87 \%$ and $88 \%$ of the energy demand by the base case building.

- Application of external solar shading or additional natural ventilation can result in a decrease of the total energy demand which is equally high as the decrease when one would apply a thermal resistance of $\mathrm{R}_{\mathrm{C}}=6.5 \mathrm{~m}\left(\mathrm{U}=0.15 \mathrm{~W} / \mathrm{m}^{2} \mathrm{~K}\right)$ instead of $\mathrm{R}_{\mathrm{C}}=3.5 \mathrm{~m}\left(\mathrm{U}=0.29 \mathrm{~W} / \mathrm{m}^{2} \mathrm{~K}\right)$.

- Increasing the short-wave reflectivity to 0.8 (SWR08) for a poorly insulated building reduces the energy demand for cooling, but results in an increase of the total yearly energy demand due to the negative effects on the yearly heating demand.

\section{Limitations and future work}

There are several limitations in this study which indicate directions for future research:

- It would be very valuable if measurement data of the energy use for heating and cooling in residential buildings would be collected in the near future. This data could be used for a more detailed validation study and, moreover, to assess the influence of building users on the energy demand and its spread in residential buildings.

- The study can be extended to include other residential buildings (apartment, detached house, etc.), and other building types, e.g. office buildings, schools, hospitals, which all have their own specific characteristics and heat balances and require an additional analysis.

- Opening the windows and lowering external solar shading appear to be the most efficient measures to reduce the cooling demand in a terraced house when active cooling would be present. However, both measures strongly rely on human behavior since both measures generally require manual intervention by the occupants of a building. This fact results in the possibility that large differences can occur in the expected energy demand reduction and the reduction in practice (e.g. Refs. [70,71]). The occupants of residential buildings should have basic knowledge on how to prevent indoor overheating 
and should be able to apply these preventive measures in an efficient way. An alternative would be the automation of these actions by a detection and control system.

- Only one type of vegetated roof is studied, which does not allow to draw general applicable conclusions from this study. Future work can include a more exhaustive assessment of the effect of vegetated roofs, and possibly also vegetated facades, on heating and energy demand in residential building. Note that a previous study by Ottelé et al. [72] also showed only very little effect of extensive vegetated roofs on the indoor air temperature when applied on well-insulated building envelopes, which agrees with the findings in the current study.

- Only a limited number of climate change adaptation measures is studied, and future studies can extend this number to include evaporative cooling, water roofs, etc. In addition, the effect of these measures on both the energy demand for heating and cooling, and on the outdoor thermal environment can be assessed.

- The study is performed using the Dutch climate, which is a maritime temperate climate according to the Köppen climate classification [69]. The work should be extended to other climates from the Köppen climate classification, and other building and construction typologies that are common in other countries and continents.

- Future work will also consist of an analysis of the different passive climate change adaptation measures for a shorter heatwave period. This study will then focus on the cooling energy demand only.

\section{Acknowledgements}

The research presented in this paper was funded by the Dutch Knowledge for Climate research program and was carried out by partners within the Climate Proof Cities research consortium.

At the time of submission, Twan van Hooff is a postdoctoral fellow of the Research Foundation - Flanders (FWO) (project FWO 1.2.R97.15N).

\section{References}

[1] IPCC. Summary for policymakers. In: Stocker TF, Qin D, Plattner G-K, Tignor M, Allen SK, Boschung J, et al., editors. Climate change 2013: the physical science basis. Contribution of working group I to the fifth assessment report of the intergovernmental panel on climate change. Cambridge, United Kingdom and New York, NY, USA: Cambridge University Press; 2013.

[2] KNMI. KNMI'14-klimaatscenario's voor Nederland; leidraad voor professionals in klimaatadaptatie. De Bilt, The Netherlands: KNMI; 2014. p. 34.

[3] Nazaroff WW. Climate change, building energy use, and indoor environmental quality. Indoor Air 2008;18:259-60.

[4] de Wilde P, Tian W. Management of thermal performance risks in buildings subject to climate change. Build Environ 2012:55:167-77.

[5] Li D, Yang L, Lam J. Impact of climate change on energy use in the built environment in different climate zones - a review. Energy 2012;42(1): $103-12$.

[6] ClimateCOST. In: Watkiss P, editor. The climatecost project. Final report. Volume 1: Europe. Sweden: Stockholm Environment Institute; 2011.

[7] Haines A, Kovats RS, Campbell-Lendrum D, Corvalan C. Climate change and human health: Impacts, vulnerability and public health. Public Health 2006;120:585-96.

[8] Chalmers P. Climate change: implications for buildings. Key findings from the intergovernmental panel on climate change fifth assessment report. 2014 http://www.cisl.cam.ac.uk/business-action/low-carbon-transformation/ipccbriefings/pdfs/briefings/IPCC_AR5_Implications_for_Buildings_Briefing_ WEB_EN.pdf.

[9] Isaac M, van Vuuren DP. Modeling global residential sector energy demand for heating and air conditioning in the context of climate change. Energy Policy 2009;37:507-21.

[10] van Kempen P. Marktanalyse en -prognose van airconditioningsystemen. Van Kempen Onderzoek en Advies, Amsterdam, The Netherlands. 2000.

[11] Entranze.http://www.entranze.enerdata.eu/\#/share-of-dwellings-with-airconditioning.html (accessed 17-02-2014).
[12] Capros P, Mantzos L, Papandreou V, Tasios N. European energy and transport: Trends to 2030 - update 2007. Luxembourg: Office for Official Publications of the European Communities; 2008.

[13] Wu A, Pett J. Cold Comfort for Kyoto?. London: ACE; 2006.

[14] Aebischer B, Henderson G, Jakob M, Catenazzi G. Impact of climate change on thermal comfort, heating and cooling energy demand in Europe. Proceedings ECEEE 2007 summer study "Saving Energy - Just do it!", France, 4-9 June 2007.

[15] Coley D, Kershaw T. Changes in internal temperatures within the built environment as a response to a changing climate. Build Environ 2010;45: 89-93.

[16] Porrit S, Shao L, Cropper P, Goodier C. Adapting dwellings for heat waves. Sustainable Cities and Society 2011;1:81-90.

[17] Porritt SM, Cropper PC, Shao L, Goodier CI. Ranking of interventions to reduce dwelling overheating during heat waves. Energy Build 2012;55:16-27.

[18] Coley D, Kershaw T, Eames M. A comparison of structural and behavioural adaptations to future proofing buildings against higher temperatures. Build Environ 2012;55:159-66.

[19] Holmes MJ, Hacker JN. Climate change, thermal comfort and energy: meeting the design challenges of the $21^{\text {st }}$ century. Energy Build 2007;39:802-14.

[20] Gupta R, Gregg M. Using UK climate change predictions to adapt existing English homes for a warming climate. Build Environ 2012;55:20-42.

[21] van Hooff T, Blocken B, Hensen JLM, Timmermans HJP. On the predicted effectiveness of climate adaptation measures for residential buildings. Build Environ 2014;82:300-16. http://dx.doi.org/10.1016/j.buildenv.2014.08.027.

[22] US Department of Energy. EnergyPlus simulation software. Available from: http://apps1.eere.energy.gov/buildings/energyplus/(accessed 27-01-2012).

[23] Albers RAW, Bosch PR, Blocken B, van den Dobbelsteen AAJF, van Hove LWA, Spit TJM, et al. Overview of challenges and achievements in the climate adaptation of cities and in the climate proof cities program. Build Environ 2015;83:1-10. http://dx.doi.org/10.1016/j.buildenv.2014.09.006.

[24] Montazeri H, Blocken B, Hensen J. Evaporative cooling by mist spraying: CFD simulation, validation and sensitivity analysis. Build Environ 2015;83: 129-41. http://dx.doi.org/10.1016/j.buildenv.2014.03.022.

[25] Gromke C, Blocken B, Janssen W, Merema B, van Hooff T, Timmermans H. CFD analysis of transpirational cooling potential of locally applied vegetative measures at building and street canyon scale: a case study for the city of Arnhem, The Netherlands. Build Environ 2015;83:11-26. http://dx.doi.org/ 10.1016/j.buildenv.2014.04.022.

[26] Toparlar Y, Blocken B, Vos P, Janssen W, van Hooff T, Montazeri H, et al. CFD simulation and validation of urban microclimate: a case study for Bergpolder Zuid, Rotterdam. Build Environ 2015;83:79-90. http://dx.doi.org/10.1016/ j.buildenv.2014.08.004.

[27] Jacobs C, Elbers J, Brolsma R, Hartogensis O, ter Moors E, Rodríguez-Carretero Márquez MT, et al. Assessment of evaporative water loss from Dutch cities. Build Environ 2015;83:27-38. http://dx.doi.org/10.1016/ j.buildenv.2014.07.005.

[28] Schrijvers PJC, Jonker HJJ, Kenjeres S, de Roode SR. Breakdown of the nighttime urban heat island energy budget. Build Environ 2015;83:50-64. http:// dx.doi.org/10.1016/j.buildenv.2014.08.012.

[29] Taleghani M, Kleerekoper L, Tenpierik M, van den Dobbelsteen A. Outdoor thermal comfort within five different urban forms in The Netherlands. Build Environ 2015;83:64-78. http://dx.doi.org/10.1016/j.buildenv.2014.03.014.

[30] van Hove LWA, Jacobs CMJ, Heusinkveld BG, Elbers JA, van Driel BL, Holtslag AAM. Temporal and spatial variability of urban heat island and thermal comfort within the Rotterdam agglomeration. Build Environ 2015;83: 91-103. http://dx.doi.org/10.1016/j.buildenv.2014.08.029.

[31] Daanen HAM, Herweijer JA. Effectiveness of an indoor preparation program to increase thermal resilience in elderly for heat waves. Build Environ 2015;83: 115-9. http://dx.doi.org/10.1016/j.buildenv.2014.04.010.

[32] Klemm W, Heusinkveld BG, Lenzholzer S, Jacobs MH, van Hove B. Psychological and physical impact of urban green spaces on outdoor thermal comfort during summertime in The Netherlands. Build Environ 2015;83:120-8. http://dx.doi.org/10.1016/j.buildenv.2014.05.013.

[33] Voskamp IM, van de Ven FHM. Planning support system for climate adaptation: composing effective sets of blue-green measures to reduce urban vulnerability to extreme weather events. Build Environ 2015;83:159-67. http://dx.doi.org/10.1016/j.buildenv.2014.07.018.

[34] Roders M, Straub A. Assessment of the likelihood of implementation strategies for climate change adaptation measures in Dutch social housing. Build Environ 2015;83:168-76. http://dx.doi.org/10.1016/j.buildenv.2014.07.014.

[35] Groot AME, Bosch PR, Buijs S, Jacobs CMJ, Moors EJ. Integration in urban climate adaptation: lessons from Rotterdam on integration between scientific disciplines and integration between scientific and stakeholder knowledge. Build Environ 2015;83:177-88. http://dx.doi.org/10.1016/ j.buildenv.2014.07.023.

[36] Crawley DB, Lawrie LK, Winkelmann FC, Buhl WF, Huang YJ, Pedersen CO, et al. EnergyPlus: creating a new-generation building energy simulation program. Energy Build 2001;33:443-57.

[37] Henninger RH, Witte MJ. EnergyPlus testing with building thermal envelope and fabric load tests from ANSI/ASHRAE standard 140-2011. 2013.

[38] Zhai Z, Johnson M-H, Krarti M. Assessment of natural and hybrid ventilation models in whole-building energy simulations. Energy Build 2011;43: $2251-61$. 
[39] Gu L, Crawley D. Overview of EnergyPlus development: new capabilities and applications for integrated building system design. In: Presented at CHAMPS 2009, Syracuse University; 2009.

[40] Olsen EL, Chen Q. Energy consumption and comfort analysis for different lowenergy cooling systems in a mild climate. Energy Build 2003;35(6):560-71.

[41] EnergyPlus. Input output reference. 2011.

[42] EnergyPlus Testing and Validation. Available from: https://energyplus.net/ testing (accessed on 15-10-2015).

[43] Agentschap NL. Referentiewoningen nieuwbouw 2013. The Netherlands: Agentschap NL, Sittard; 2013.

[44] Bouwbesluit online. Bouwbesluit Nederland. Available from: http://www. bouwbesluitonline.nl/(accessed 12-03-2012).

[45] ISSO 32. Publicatie 32: uitgangspunten temperatuursimulatieberekeningen. Rotterdam, The Netherlands: Stichting ISSO; 2011.

[46] Ministerie van VROM. Energiegedrag in de woning. 2010.

[47] ASHRAE. Handbook - fundamentals (SI) (Vol. 18). American society of heating. Atlanta, USA: Refrigerating and Air-Conditioning Engineers, Inc.; 2009.

[48] Bretz S, Akbari H, Rosenfeld A, Taha H. Implementation of solar-reflective surfaces: materials and utility programs. Berkeley, CA, USA: Lawrence Berkeley laboratory, University of California; 1992.

[49] Gaffin S, Khanbilvardi R, Rosenzweig C. Development of a green roof environmental monitoring and meteorological network in New York city. Sensors 2009;9:2647-60.

[50] Scurlock JMO, Asner GP, Gower ST. Worldwide historical estimates of leaf area Index, 1932-2000. ORNL/TM-2001/268, Oak Ridge National laboratory, environmental sciences Division. 2001.

[51] Zhang Y, Barrett P. Factors influencing occupants' blind-control behaviour in a naturally ventilated office building. Build Environ 2012;54:137-47.

[52] KNMI. KNMI weather data. Available from: http://www.knmi.nl/climatology/ daily_data/download.html (accessed 2801 2014).

[53] Scott P, Stone D, Allen M. Human contribution to the European heatwave of 2003. Nature 2004;432:610-4.

[54] NEN 5060. Hygrothermische eigenschappen van gebouwen - Referentieklimaatgegevens. Delft, The Netherlands: Nederlands NormalisatieInstituut (NNI); 2008.

[55] Mirsadeghi M, Costola D, Blocken B, Hensen JLM. Review of external convective heat transfer coefficient models in building energy simulation programs: implementation and uncertainty. Appl Therm Eng 2013;56: 134-51.

[56] Liddament MW. AIVC: a guide to energy efficient ventilation. Coventry, UK: AIVC; 1996.

[57] CEN (European Committee for Standardization) 2005. EN ISO 15927-4:2005 Hygrothermal Performance of Buildings - Calculation and Presentation of
Climatic Data - Part 4: hourly data for assessing the annual energy use for heating and cooling. Brussels: European Committee for Standardization; 2005.

[58] Ogoli DM. Predicting indoor temperatures in closed buildings with high thermal mass. Energy Build 2003;35:851-62.

[59] Givoni B. Effectiveness of mass and night ventilation in lowering the indoor daytime temperatures. Part I: 1993 experimental periods. Energy Build $1998 ; 28: 25-32$

[60] Hoes P, Trcka M, Hensen JLM, Hoekstra Bonnema B. Investigating the potential of a novel low-energy house concept with hybrid adaptable thermal storage. Energy Convers Manage 2011;52(6):2442-7.

[61] Hoes P, Hensen JLM. The potential of lightweight low-energy houses with hybrid adaptable thermal storage: comparing the performance of promising concepts. Energy Build 2016;110:79-93.

[62] Wang H, Chen Q. A semi-empirical model for studying the impact of therma mass and cost-return analysis on mixed-mode ventilation in office buildings. Energy Build 2013;67:267-74.

[63] Balaras CA. The role of thermal mass on the cooling load of buildings. An overview of computational methods. Energy Build 1996;24:1-10.

[64] Kalema T, Jóhannesson G, Pylsy P, Hagengran P. Accuracy of energy analysis of Buildings: a comparison of a monthly energy balance method and simulation methods in calculating the energy consumption and the effect of thermal mass. J Build Phys 2008;32:101-30.

[65] Cheng V, Ng E, Givoni B. Effect of envelope colour and thermal mass on indoor temperatures in hot humid climate. Sol Energy 2005;78:528-34.

[66] Akbari H, Bretz S, Kurn D, Hanford J. Peak power and cooling energy savings of high-albedo roofs. Energy Build 1997;25:117-26.

[67] Bretz S, Akbari H. Long-term performance of high-albedo roof coatings. Energy Build 1997;25:159-67.

[68] Synnefa A, Saliari M, Santamouris M. Experimental and numerical assessment of the impact of increased roof reflectance on a school building in Athens. Energy Build 2012;55:7-15.

[69] Köppen W, Geiger R. Klima der Erde (Climate of the Earth). Wall Map 1:16 Mill. Klett-Perthes, Gotha. 1954

[70] Fabi V, Andersen RV, Corgnati S, Olesen BW. Occupants' window opening behaviour: a literature review of factors influencing occupant behaviour and models. Build Environ 2012;58:188-98.

[71] Andersen RV, Fabi V, Toftum J, Corgnati SP, Olesen BW. Window opening behaviour modelled from measurements in Danish dwellings. Build Environ 2013;69:101-13.

[72] Ottelé $\mathrm{M}$. The green building envelope: vertical greening [PhD thesis]. Delft. The Netherlands: Delft University of Technology; 2011. http://repository. tudelft.nl/assets/uuid:1e38e393-ca5c-45af-a4fe-31496195b88d/The\% 20Green\%20Building\%20Envelope\%20def.pdf. 